\title{
Novel Amphiphilic Lantern-type Cu(II)-Pd(II) Complex Coordinated with Four 2-Pyridone Derivatives Having A Long Alkyl Chain
}

\author{
Naoko Ichieda, Hidemiki Hakamata, Tomohiro Ozawa, Yasuhiro Funahashi, Koichiro Jitsukawa, \\ and Hideki Masuda*
}

Department of Material Science and Engineering, Graduate School of Engineering, Nagoya Institute of Technology,
Gokiso-cho, Showa-ku, Nagoya 466-8555, Japan

\begin{abstract}
Novel amphiphilic dinuclear complex, copper(II) tetrakis(6-hydroxy-nicotinic dodesyl amide)palladium(II) complex with long hydrophobic alkyl chains $\left(\left[\mathrm{CuPd}(\mathrm{hnda})_{4}(\mathrm{DMF})\right](\mathbf{1})\right)$, was synthesized and characterized by electronic absorption, IR, and ESR spectroscopic and elemental and X-ray diffraction methods. X-ray analysis of the single crystal of 1 obtained from a DMF/ $\mathrm{H}_{2} \mathrm{O}$ mixed solution revealed a lantern-type dinuclear $\mathrm{Pd}(\mathrm{II})-\mathrm{Cu}$ (II) structure bridged by four HNDA ligands, in which $\mathrm{Pd}(\mathrm{II})$ and $\mathrm{Cu}(\mathrm{II})$ ions were respectively tetrakis-coordinated with the nitrogen and oxygen atoms of four HNDA ligands in the equatorial plane. The apical site of $\mathrm{Cu}(\mathrm{II})$ atom was occupied by a DMF molecule, and the apical site of $\mathrm{Pd}(\mathrm{II})$ atom was weakly linked with a water molecule. The four HNDA dodesyl groups extended outward to form a hydrophobic layer, while the lantern-type dinuclear cores formed a hydrophilic layer. They constructed alternate layered structures composed of hydrophobic and hydrophilic groups. DMF solution of 1 gave an intense ESR spectrum $\left(g_{\perp}=2.08, g_{/ /}=2.41,\left|\mathrm{~A}_{/ /}\right|=9.89 \mathrm{mT}\right)$ characteristic of a distorted square planar structure, to which the addition of water broadened it. These behaviors were discussed in connection with the structures of amphiphilic complex 1.
\end{abstract}

\section{INTRODUCTION}

Amphiphilic assemblies range from simple structures, such as micelles, vesicles, microemulsions, and mono- and bilayers, to highly complex biological architectures as membranes. The shape of the aggregates is dependent upon the attractive and repulsive components of the free energy of their formation [1-3]. Recent development of a bottom-up self-assembling technique for fabricating devices on a nanometer scale has found wide applications, including electronic [4], magnetic [5], and photonic materials [6] and quantum dots [7]. The synthesis of these nanomaterials generally involves organic surfactants or amphiphilic copolymers as templates in directing the formation of hierarchical structures. Various geometric shapes such as nano-spheres [8], fibers [9], -rings [10], and -filaments [11], as few examples, are documented. In general, these bottom-up syntheses are driven by the noncovalent bonding forces, such as electrostatic charge attraction, hydrogen bonding, van der Waals forces, and hydrophobic interactions.

Previously we reported lantern-type M-M' complexes bridged by $\mathrm{N} \sim \mathrm{O}$ or $\mathrm{O} \sim \mathrm{N} \sim \mathrm{O}$ ligands $(\mathrm{M}=\mathrm{Na}, \mathrm{K}, \mathrm{Cs}, \mathrm{V}=\mathrm{O}$, $\mathrm{Cu} ; \mathrm{M}^{\prime}=\mathrm{Pd}, \mathrm{Pt} ; \mathrm{N} \sim \mathrm{O}$ ligand $=2$-pyridone; $\mathrm{O} \sim \mathrm{N} \sim \mathrm{O}$ ligand $=$ 1-methyluracilato, phthalimide) and confirmed that some of them formed infinite nanowire structures along the M-M' bond axis [12]. If we employed the ligand with a hydrophobic long alkyl chain and a functional metal ion to this system, a high performance material with a columnar or layer

*Address correspondence to this author at the Department of Material Science and Engineering, Graduate School of Engineering, Nagoya Institute of Technology, Gokiso-cho, Showa-ku, Nagoya 466-8555, Japan;

E-mail: masuda.hideki@nitech.ac.jp structure would expect to be constructed. In this study, we tried to construct such a functional amphiphilic material in order to find an essential factor to control the formation of columnar or layer materials. As one example, we designed and prepared the lantern-type $\mathrm{Cu}(\mathrm{II})-\mathrm{Pd}(\mathrm{II})$ complex, which is coordinated by four 2-pyridone derivatives having a long alkyl chain (hnda). Here we describe the synthesis, property, and structure in solution and solid states.

\section{EXPERIMENTAL SECTION}

\section{Materials}

All the chemicals used in this study, which are of reagent grade, were purchased and were used without prior purification.

\section{Synthesis of 6-hydroxy-nicotinic dodesyl amide (Hhnda)}

To an MeCN solution (40 mL) containing 6-hydroxynicotinic acid $\left(1.1 \times 10^{-2} \mathrm{~mol}, 1.54 \mathrm{~g}\right)$ and 2-chloro-1methylpyridinium iodide $\left(1.3 \times 10^{-2} \mathrm{~mol}, 3.33 \mathrm{~g}\right)$ were added dodecylamine $\left(1.1 \times 10^{-2} \mathrm{~mol}, 2.03 \mathrm{~g}\right)$ and $\mathrm{Et}_{3} \mathrm{~N}\left(2.6 \times 10^{-2}\right.$ mol, $2.57 \mathrm{~g})$. The mixed solution was refluxed at $80{ }^{\circ} \mathrm{C}$ for two days to give the product as white powder. The product was filtrated out and washed with a small amount of alkaline water of $\mathrm{Et}_{3} \mathrm{~N}$ and $\mathrm{CHCl}_{3}$, respectively, and dried under vacuum, which was obtained as a white powder $(2.42 \mathrm{~g}$, Yield $71 \%$ ). It was characterized by ${ }^{1} \mathrm{H}-\mathrm{NMR}$ spectroscopy and elemental analysis. ${ }^{1} \mathrm{H}$ NMR spectroscopy (DMSO- $d_{6}$, Varian Gemini-300 $300 \mathrm{MHz}, \delta / \mathrm{ppm}): \delta 11.92$ [br], 8.12 [br], $7.96[1 \mathrm{H}, \mathrm{d}, J=2.4 \mathrm{~Hz}], 7.85[1 \mathrm{H}, \mathrm{d}, J=9.6 \mathrm{~Hz}], 6.33[1 \mathrm{H}$, $\mathrm{d}, J=9.6 \mathrm{~Hz}], 1.46[2 \mathrm{H}, \mathrm{m}], 1.26[20 \mathrm{H}, \mathrm{m}], 0.86[3 \mathrm{H}, \mathrm{t}, J=$ $6.6 \mathrm{~Hz}$ ] (Chart 1). Anal. Calcd. for $\mathrm{C}_{18} \mathrm{H}_{30} \mathrm{~N}_{2} \mathrm{O}_{2}(\%): \mathrm{C}$, 70.55; H, 9.87; N, 9.14; Found: C, 70.31; H, 9.67; N, 9.12. 


\section{Preparation of $\left[\mathrm{CuPd}(\mathrm{hnda})_{4}(\mathrm{DMF})\right](1)$}

To the mixed DMF solution $(20 \mathrm{~mL})$ of $\left(\mathrm{Et}_{4} \mathrm{~N}\right)_{2}\left[\mathrm{PdCl}_{4}\right]$ $\left(5.0 \times 10^{-5} \mathrm{~mol}, 25.4 \mathrm{mg}\right)$ and 4 eq. of Hhnda $\left(2.0 \times 10^{-4} \mathrm{~mol}\right.$, $61.3 \mathrm{mg})$ deprotonated with $\mathrm{Et}_{3} \mathrm{~N}\left(4.0 \times 10^{-2} \mathrm{~mol}, 41.1 \mathrm{mg}\right)$, $\mathrm{CuCl}_{2}\left(5.0 \times 10^{-5} \mathrm{~mol}, 6.7 \mathrm{mg}\right)$ was added and reacted over night. Addition of $\mathrm{H}_{2} \mathrm{O}$ to the resultant solution gave yellow green crystals of the product. X-ray analysis was conducted with a single crystal recrystallized from DMF. $(41.8 \mathrm{mg}$, Yield 57\%). Anal. Calcd. for $\mathrm{C}_{75} \mathrm{H}_{123} \mathrm{~N}_{9} \mathrm{O}_{9}$ CuPd-DMF-4.5 $\mathrm{H}_{2} \mathrm{O}$ : C, 57.87; H, 8.65; N, 8.65. Found: C, 57.95; H, 8.94; $\mathrm{N}, 8.69$.

Physical Measurements. Elemental analyses were performed using a Perkin-Elmer PE2400II CHN/O fullautomatic analyzer. Electronic absorption spectra were recorded on a JASCO V-570 UV-vis spectrometer using 1.0 cm-optical-length quartz cells. ${ }^{1} \mathrm{H}$ NMR spectra were obtained with Bruker AVANCE-600 spectrometer. IR spectra were measured with JASCO FT/IR-410 spectrometer by $\mathrm{KBr}$ method. ESI-mass spectra were obtained by Micromass LCT ESI-TOF spectrometer.

\section{Crystal Structure Analysis}

Crystal data: $\left[\mathrm{CuPd}(\mathrm{hnda})_{4}(\mathrm{DMF})\right] \cdot 2.3 \mathrm{H}_{2} \mathrm{O} \cdot \mathrm{DMF}$ (1); $\mathrm{C}_{78} \mathrm{H}_{123} \mathrm{~N}_{10} \mathrm{O}_{12.3} \mathrm{PdCu}, M=1567.64$, monoclinic, space group $P 2{ }_{1} / a$ (\#14), $a=17.939(5) \AA, b=21.906(6) \AA, c=23.180(7)$ $\AA, \beta=111.839(3)^{\circ}, V=8455(4) \AA^{3}, Z=4, \mu(\mathrm{Mo} K \alpha)=$ $5.257 \mathrm{~cm}^{-1}$. A total of 19412 unique reflections were collected with graphite-monochromated Mo $K \alpha$ radiation $(\lambda=$ $0.71070 \AA$ ) on Rigaku Mercury diffractometer, of which all reflections were used in the structure analysis and refinement using the CrystalStructure program. Empirical absorption correction was applied. Final $R_{1}$ and $R_{\mathrm{w}}$ factors were 0.0933 and 0.1623 , respectively.

\section{RESULTS AND DISCUSSION}

A new ligand, hnda, was synthesized by the reaction of 6-hydroxy-nicotinic acid and dodecylamine in $\mathrm{MeCN}$. After washing, it was obtained as a white powder with good yield and was characterized by IR, ESI-mass and ${ }^{1} \mathrm{H}$ NMR spectroscopies and elemental analysis. $\left[\mathrm{CuPd}(\mathrm{hnda})_{4} \mathrm{DMF}\right]$ (1) was prepared by mixing DMF solutions of $\left(\mathrm{Et}_{4} \mathrm{~N}\right)_{2}\left[\mathrm{PdCl}_{4}\right]$ and 4 eq. of Hhnda molecule deprotonated with $\mathrm{Et}_{3} \mathrm{~N}$, followed by addition of $\mathrm{CuCl}_{2}$. Addition of $\mathrm{H}_{2} \mathrm{O}$ gave yellowgreen crystals and $\mathrm{X}$-ray structure analysis was conducted with the single crystal recrystallized from DMF.

The molecular structure of complex $\mathbf{1}$ is essentially the same as those of previously reported complexes, $[\mathrm{CuPd}(2-$ pyr $)_{4}($ py $\left.)\right]$ and $\left[\operatorname{CuPt}(2-\text { pyr })_{4}(\right.$ py $\left.)\right]($ pyr $=$ pyridone; py $=$ pyridine) [13] (Fig. 1). For 1, the Pd(II) ion was coordinated by four deprotonated hnda ligands through nitrogen atoms in a square-planar geometry. The $\mathrm{Pd}-\mathrm{N}$ distances $(\mathrm{Pd}(1)-\mathrm{N}(1)=$ 2.016(5), $\operatorname{Pd}(1)-\mathrm{N}(2)=2.021(6), \operatorname{Pd}(1)-\mathrm{N}(3)=2.047(5)$, $\operatorname{Pd}(1)-\mathrm{N}(4)=2.054(6) \AA$ ) and $\mathrm{N}-\mathrm{Pd}(1)-\mathrm{N}$ angles $(\mathrm{N}(1)-$ $\operatorname{Pd}(1)-\mathrm{N}(2)=87.2(2), \quad \mathrm{N}(2)-\mathrm{Pd}(1)-\mathrm{N}(3)=91.0(2), \mathrm{N}(3)-$ $\left.\operatorname{Pd}(1)-\mathrm{N}(4)=88.4(2), \mathrm{N}(1)-\mathrm{Pd}(1)-\mathrm{N}(4)=93.1(2)^{\circ}\right)$ were very similar to those of $\left[\mathrm{CuPd}(2-\mathrm{pyr})_{4}(\mathrm{py})\right](\mathrm{Pd}-\mathrm{N}=2.012(3)-$ 2.040(4) $\AA$, N-Pd-N $\left.=88.9(1)-90.6(1)^{\circ}\right)$ and $[\mathrm{CuPt}(2-$ pyr)4(py)] (Pt-N = 2.010(5)-2.049(6) $\AA$, N-Pt-N = 88.7(3)$\left.91.4(3)^{\circ}\right)$ ). In an axial site of the Pd(II) ion, the host space

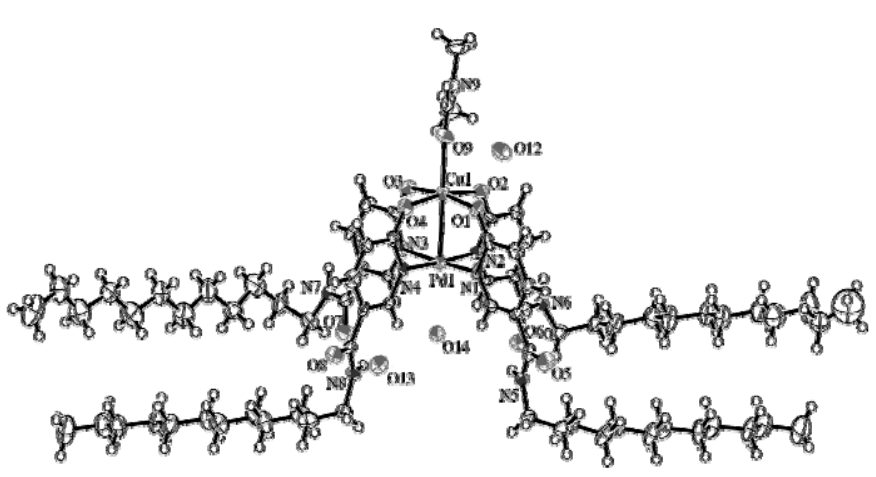

(a)

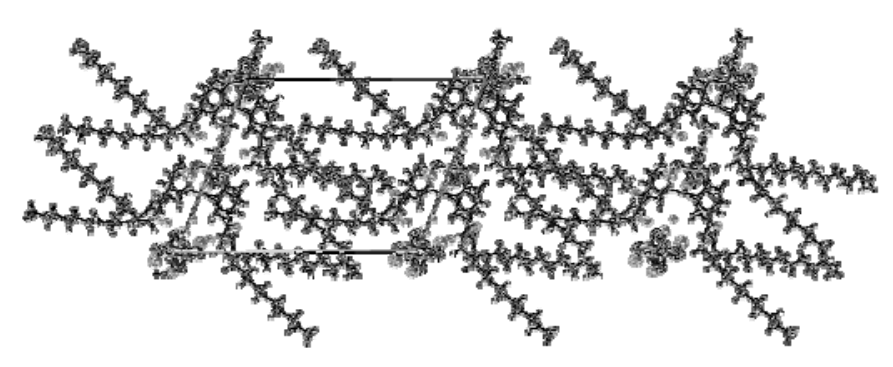

(b)

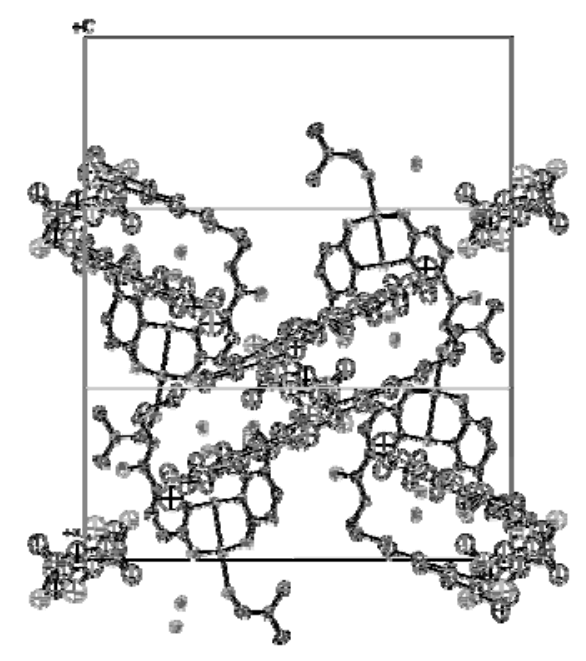

(c)

Fig. (1). X-ray structures of complex 1 (a) viewed along $b$ axis (b) and hydrophilic zig-zag wire (c).

surrounded by carbonyl oxygens was formed, which captured a $\mathrm{Cu}(\mathrm{II})$ ion as a guest $(\mathrm{Cu}(1)-\mathrm{O}(1)=1.963(5), \mathrm{Cu}(1)-$ $\mathrm{O}(2)=2.009(6), \mathrm{Cu}(1)-\mathrm{O}(3)=1.993(5), \mathrm{Cu}(1)-\mathrm{O}(4)=$ 2.035(5) $\AA$ ). The distance between $\mathrm{Pd}$ and $\mathrm{Cu}$ atoms was 2.5432(13) $\AA$, which is shorter than the sum of their metallic bond radii $(\operatorname{Pd}(1.38 \AA)+\mathrm{Cu}(1.28 \AA)=2.66 \AA)$. Another axial sites of the $\mathrm{Cu}(\mathrm{II})$ and the $\mathrm{Pd}(\mathrm{II})$ atoms were occupied 


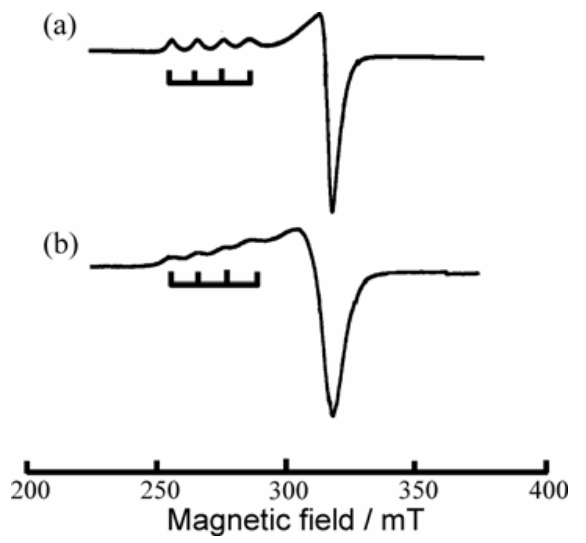

Fig. (2). ESR spectra of complex 1 before (a) and after (b) addition of $\mathrm{H}_{2} \mathrm{O}$ with oxygen atoms of DMF $(\mathrm{Cu}(1)-\mathrm{O}(9)=2.131(6) \AA$, $\left.\mathrm{Pd}(1)-\mathrm{Cu}(1)-\mathrm{O}(9)=178.95(15)^{\circ}\right)$ and water molecules $(\operatorname{Pd}(1)-O(14)=2.648(19) \AA)$, respectively. Viewed from the top (Fig. 1a), four alkyl chains extended outward in pairs, in which the two chains crossed each other. To the amide site of the alkyl chains, nearest neighbor $\mathrm{H}_{2} \mathrm{O}$ molecules were interacted through hydrogen bonds $(\mathrm{O}(7) \cdots \mathrm{O}(13)=2.790(7)$ $\AA, \mathrm{O}(13) \cdots \mathrm{O}(14)=2.580(16) \AA, \mathrm{N}(8) \cdots \mathrm{O}(13)=2.887(8) \AA$, $\mathrm{O}(6) \cdots \mathrm{O}(12)=2.807(7) \AA, \mathrm{N}(5) \cdots \mathrm{O}(12)=2.904(7) \AA)$.

As shown in Fig. (1b), the long alkyl chains were selfassembled through hydrophobic interaction to form alternate layers composed of hydrophilic Pd coordination sites and hydrophobic alkyl chains. These layers stacked alternately along $c$ axis and the interval of the hydrophobic layer, as estimated from the distance between $\mathrm{Cu}$ atoms of adjacent molecules, was ca. $23 \AA$. In a hydrophilic layer (Fig. 1c), the $\mathrm{O}(9)$ atom was linked to $\mathrm{O}(14)$ atom through a hydrogen bond with the distance of 3.202(18) $\AA$ to form 1D-zig-zag wire along $a$ axis. The closest distance of $\mathrm{Cu}(\mathrm{II})$ atoms were $7.95 \AA$. One more DMF molecule, which was confirmed by elemental analysis, was packed in hydrophilic layers in disorder. $\mathrm{O}(10)$ and $\mathrm{O}(11)$ atoms of DMF interacted weakly to amide $\mathrm{N}$ or pyridonato $\mathrm{N}$ atoms with distances of $3.245 \AA$ $(\mathrm{O}(10) \cdots \mathrm{N}(7)), 3.375 \AA \quad(\mathrm{O}(11) \cdots \mathrm{N}(1)), 3.344 \AA \quad(\mathrm{O}(11) \cdots \mathrm{N}$ (4)), respectively.

The electronic absorption spectrum of complex 1 in DMF solution showed two bands around $\sim 350 \mathrm{~nm}$ (shoulder peak) and at $815 \mathrm{~nm}\left(\varepsilon=235 \mathrm{M}^{-1} \mathrm{~cm}^{-1}\right)$, and they were assigned to $d$ - $d$ transition bands of a $\mathrm{Pd}(\mathrm{II})$ and a $\mathrm{Cu}(\mathrm{II})$ ion, respectively. The $d$ - $d$ band of $\mathrm{Cu}$ ion in the lower energy region suggests that the $\mathrm{Cu}(\mathrm{II})$ ion is kept in the host space also in solution.

Its frozen solution ESR spectrum showed an intense and clear signal characteristic of a $\mathrm{Cu}$ (II) species (Fig. 2a), whose parameters were $g_{\perp}=2.08, g_{/ /}=2.41,\left|\mathrm{~A}_{/ /}\right|=9.89 \mathrm{mT}$. The $\left|\mathrm{A}_{/ /}\right|$value was rather small relative to those of typical square-planar one $(\sim 18 \mathrm{mT})$, implying a distorted squareplanar geometry around $\mathrm{Cu}$ atom. This feature is also seen in similar complex, $\left[\mathrm{CuPd}(2-\mathrm{pyr})_{4}\left(\mathrm{H}_{2} \mathrm{O}\right)\right]\left(g_{\perp}=2.08, g_{/ /}=2.42\right.$, $\left|\mathrm{A}_{/ /}\right|=10.0 \mathrm{mT}$ ) [13]. However, the addition of water to the DMF solution of $\mathbf{1}$ broadened the ESR spectrum $\left(\mathrm{g}_{\perp}=2.10, \mathrm{~g}_{/ /}=2.42,\left|\mathrm{~A}_{/ /}\right|=10.4 \mathrm{mT}\right)$ (Fig. 2b), suggesting a weak antiferromagnetic interaction between $\mathrm{Cu}$ ions.

In this paper, we studied the preparation and characterization of the lantern-type $\mathrm{Cu}-\mathrm{Pd}$ complex bridged by hnda ligands in order to understand the factor to control the structures of amphiphilic materials, which includes both a hydrophilic $\mathrm{Cu}-\mathrm{Pd}$ core and hydrophobic long alkyl chains. It formed the layer structure alternately stacked with hydrophobic and hydrophilic layers in the solid state. That is, it preferred the layer structure to the columnar one. This was examined also in solution. This may be explained as follows: the hydrophobic alkyl chains of hnda ligand are too small and too short to form the columnar structure.

\section{REFERENCES}

[1] Israelachvilli, J. N. Intermolecular and Surface Forces: With Application to Colloidal and Biological Systems; Academic Press: New York, 1985.

[2] (a) Micellization, Solubilization and Microemulsions; K. L. Mittal, Ed.; Plenum Press: New York, 1977; Vol. 1 and 2. (b) Solution Chemistry of Surfactants; K. L. Mittal, Ed.; Plenum Press: New York, 1979.

[3] Nagarajan, R.; Ruckenstein, E. Aggregation of amphiphiles as micelles or vesicles in aqueous media. J. Colloid Interf. Sci., 1979, 71,580 .

[4] Kagan, C. R.; Mitzi, D. B.; Dimitrakopoulos, C. D. Organicinorganic hybrid materials as semiconducting channels in thin-film field-effect transistors. Science, 1999, 286, 945.

[5] Nawa, M.; Baba R.; Nakabayashi S.; Dushkin, C. Ordering effect of high magnetic field on silver nanoparticle arrays for electrontransfer devices. Nano Lett., 2003, 3, 293.

[6] Zakhidov, A. A.; Baughman, R. H.; Iqbal, Z.; Cui, C.; Khayrullin, I.; Dantas, S. O.; Marti, J.; Ralchenko, V. G. Carbon structures with three-dimensional periodicity at optical wavelengths. Science, 1998, 282, 897.

[7] Wang, C.; Shim, M.; Guyot-Sionnest, P. Electrochromic nanocrystal quantum dots. Science, 2001, 291, 2390.

[8] Xia, Y.; Yang, P.; Sun, Y.; Wu, Y.; Mayers, B.; Gates, B.; Yin, Y.; Kim, F.; Yan, H. One-dimensional nanostructures: synthesis, characterization, and applications. Adv. Mater., 2003, 15, 353.

[9] Hartgerink, J. D.; Beniash, E.; Stupp, S. I. Self-assembly and mineralization of peptide-amphiphile nanofibers. Science, 2001, 294, 1684.

[10] Jenekhe, S. A.; Chen, X. L. Self-assembly of ordered microporous materials from rod-coil block copolymers. Science, 1999, 283, 372.

[11] Li, M.; Schnablegger, H.; Mann, S. Coupled synthesis and selfassembly of nanoparticles to give structures with controlled organization. Nature, 1999, 402, 393.

[12] a) Mizutani, M.; Jitsukawa, K.; Masuda, H.; Aoyama, Y.; Einaga, H. Formation of a novel diaqua disodium tetrakis(1methyluracilato)palladium complex with a unique supramolecular channel structure. Chem. Lett., 1998, 663. b) Mizutani, M.; Miwa, S.; Fukushima, N.; Funahashi, Y.; Ozawa, T.; Jitsukawa, K.; Masuda, H. Syntheses and structures of tetrakis(1-methyluracilato) palladium complexes capturing alkali metal ions. A new type of metallo-podand. Inorg. Chim. Acta, 2002, 339, 543.

[13] Ichieda, N.; Kamimura, T.; Wasada-Tsutsui, Y.; Funahashi, Y.; Ozawa, T.; Jitsukawa, K.; Masuda, H. Metal-metal bond formed in Tetrakis(2-pyridonato)Copper(II)- Platinum(II)/Palladium(II) Complexes. Chem. Lett., 2008, 1220. 